\title{
25 Research Soure \\ Modified Protocol to Use Platelet Rich Fibrin (PRF) as a local antibiotic delivery system - In Vitro study
}

MHD Bahaa Aldin Alhaffar ( $\sim$ bhaa.alhafar@gmail.com )

Damascus University https://orcid.org/0000-0002-9147-189X

\section{Lama Ayoub Shibibe}

Damascus University

Chadi Soukkarieh

Damascus University

\section{Ali Abou Sulaiman \\ Damascus University}

\section{Research Article}

Keywords: Antibiotic, PRF, Plasma Concentrate, Biomaterial

Posted Date: May 24th, 2021

DOI: https://doi.org/10.21203/rs.3.rs-101123/v2

License: (9) This work is licensed under a Creative Commons Attribution 4.0 International License.

Read Full License 


\section{Abstract}

Background: Plasma concentrate products have Rapidly developed during the last few years, and it had significantly improved regenerative medicine because of its specific features which enhance healing and reduce pain after surgeries. this research aims to improve the antibacterial effectiveness of PRF by adding different forms of antibiotics and evaluate the physical and antibacterial properties of the new PRF.

Methods: In-Vitro experimental study was conducted; modified protocol was used which use two stages of centrifuging was used prepare PRF. Bacterial colonies and Miller-Hinton medium was prepared. Two types of bacteria were used for the culturing and incubation (Staphylococcus aureus, Enterococcus faecalis). Different forms and volumes of antibacterial agents (Lincomycin) were incorporated with the PRF. Physical and antibacterial properties were evaluated.

Results: ampoule and solution forms had the highest levels of bacterial growth inhibiting, and best physical properties, bacterial inhibiting lasted for 10 days in culture. Significant difference was noticed between the modified PRF and the control group $(p<0.05)$. adding $(0.5 \mathrm{ml})$ of ampoule form had the best results on both antibacterial and physical properties of the new PRF.

Conclusion: The protocol proposed in this study succeeded to improve the antibacterial activity of the PRF with preserving the physical properties. No significant difference in physical properties were noticed between control group and PRF with antibiotic.

Significance and impact of the study: PRF can be used as a local antibiotic delivering biomaterial adjacent to minor surgery, the results of this study can be used to reduce the post-operative infection that is frequent after oral surgeries.

\section{Background:}

Plasma concentrate products was first described in the 1970s, and it have significantly affected regenerative biomedicine (1), it can be used adjacent to surgical procedure (2), to enhance wound healing (3) and to release growth factors, which will eventually reduce the post-operative complications (4). Platelet rich plasma (PRP) was the first generation of platelet concentrates, it combined both fibrin sealant and growth factors properties (5). However, PRP preparation had many limitations $(6,7)$, it requires a complicated method with two stage centrifuging and the use of anticoagulant (8). Choukroun et al. in 2001 introduced the second generation of platelet concentrate, which is platelet rich fibrin (PRF) (9). The use of PRF eliminates the risk of using bovine thrombin (10) and has a very simple preparation method (9).

During the centrifugation, platelets are activated and their massive degranulation implies a very significant cytokine release, because platelet cytokines are trapped in the fibrin meshes $(11,12)$, the quantity of growth factors such as PDGF-BB, TGFb-1, and IGF-1 within the PRF makes it usable as a 
healing concentrate (12). Moreover, PRF has an antimicrobial activity against wide range of bacteria, however, this activity is limited in PRF compared to PRP or leucocyte platelet rich fibrin (L-PRF) (13).

Researchers did more advances to the centrifugation protocol creating different masses of platelet, and each product had a specific feature (14). PRF can improve wound healing and reduce the discomfort after surgeries (15), injectable platelet rich fibrin (I-PRF) had an effect on bone regeneration (16), (L-PRF) and advanced platelet rich fibrin (A-PRF) have a lot of application in dentistry and especially in periodontal tissue regeneration (17). More advances and improvement to the production protocol resulted in different masses of platelets with different application in dentistry, lower speeds of centrifugation are being used to create Liquid-PRF which primary composes of fibrinogen and thrombin that has 10-15 minutes before it converts to fibrin (18),

Lately, attempts have been made to improve the physical and antimicrobial activity of PRF, a recent study tested the ability of using PRF as a local antibiotic releasing device by incorporating antibiotic agent with PRF (19), Likewise, Khurshid et al added silver nanoparticles (SNP) to L-PRF to improve the antibacterial activity(20), those studies had positive results, however, they did not introduce a unified protocol that makes antibiotic enhanced PRF reproducible.

Hence, developing advanced and improved forms of platelet concentrate products are still the main focus of biomedical research, in order to enhance tissue regeneration after oral surgeries and to reduce its complications, especially infection which remain the main complication after oral surgeries (21), therefore, in this research we aim to develop and introduce a protocol for incorporating antibiotic with platelet rich fibrin to use it as a local antibiotic delivery system.

\section{Aim of the research:}

Evaluate the physical and antibacterial properties of PRF after adding antibiotic agents using a modified protocol.

\section{Materials And Methods:}

\section{Study design:}

In-vitro experimental study was conducted in the laboratory of Biology - Faculty of Science - Damascus University - Syria.

\section{Ethical approvals:}

Ethical approvals were obtained from higher committee for medical research at Damascus University and from the scientific research committee at the faculty of Dental Medicine - Damascus university ( $N$ : 1059 $\mathrm{t} / \mathrm{m}$ date: 15-12-2019), All methods were carried out in accordance with relevant guidelines and regulations. 
Informed consent was obtained from all participants before participating in the research.

\section{Sample:}

Twelve Healthy volunteers were included, each donated $(40 \mathrm{ml})$ of blood, age ranged between 24-32, research procedure and expected results were explained to each volunteer, and written consent form were collected. Sample inclusion criteria was:

- Healthy volunteers.

- No systematic or blood diseases.

- non-smokers.

- did not take any kind of antibiotics during the last month.

\section{Preparation protocol:}

A modified protocol to the original protocol by Choukroun et al (9) was used to produce PRF with antibiotics, the main difference was two-staged centrifuging, the first one is by using plastic tubes, and the second using glass tubes, the following explain the protocol in details:

1. $40 \mathrm{ml}$ of blood were collected from the volunteers.

2. The blood samples were divided into $4(10 \mathrm{ml})$ plastic tubes without anticoagulant, plastic tubes can help to delay the PRF formation, therefore, it can be easily isolate the middle layer with the antibacterial agent from the tube in a liquid form (22).

3. The tubes were immediately centrifuged at $3000 \mathrm{rpm}$ (400 g), for 10 minutes. (Hettich EBA 200 Centrifuge, Germany)

4. Three layers are formed, erythrocytes concentrated in the lower part, fibrin enriched with platelets in the middle, and serum in the upper part. Immediately, the middle third from each tube was transported using a $5 \mathrm{ml}$ plastic syringe to a $5 \mathrm{ml}$ glass tube with a minimum time interval, glass tubes can enhance the clot formation by the interaction between the silica in glass and the palates in order to create fibrin clot (23).

5. Fibrin clot is finally formed into the glass tube, and then it is ready to be cultured in the Miller-Hinton plates, no need to separate the PRF clot from the RBC layer with this protocol.

\section{Research variables:}

- physical properties were assessed by measuring the length and consistency (tested by compression) of the PRF clot.

- Antibacterial activity was assessed by measuring the radius of bacterial growth inhibiting, measurement was done from the center of the sample to the edge of the bacteria inhibiting (Figure N.1), pictures of 
Miller-Hinton plates were taken using digital camera (Canon 1200D, macro lens $0.25 \mathrm{~m} / 0.8 \mathrm{ft}$ ) at each time interval, Image-J software V.1.52a (Wayne Rasband, National Institutes of Health, USA) was used to make the measurements.

- Measurements were done at four-time intervals: T1: after 24 hours (one day), T2: after 48 hours (two days), T3: after 120 hours (five days), T4: after 240 hours (ten days).

- Staphylococcus aureus and Enterococcus faecalis were used to test the antibacterial activity of PRF, both bacteria are known to cause infection after oral surgeries. Bacteria were isolated from Damascus university hospital and incubated at $37^{\circ} \mathrm{C}$ for 24 hours. The density of the bacterial colonies was set to 0.5 MacFarland. Mueller-Hinton agar (Himedia- India) was prepared for the culturing and incubation.

- The antibiotic agent used in this research is Lincomycin, three forms of the antibiotic were used, Ampoule: Lincomycin $600 \mathrm{mg}(0.5 \mathrm{ml}$, or $1.0 \mathrm{ml})$. Solution: one capsule of lincomycin $600 \mathrm{mg}$ was added to $10 \mathrm{ml}$ of saline, and two volume of solution was then added to the PRF $(0.5 \mathrm{ml}$, or $1.0 \mathrm{ml})$. Powder: lincomycin $600 \mathrm{mg}$ (capsule) was used, 100 and $50 \mathrm{mg}$ was measured using electronic scale and added to PRF.

\section{Statistical analysis:}

SPSS V.22 (statistical package for social science, IBM, 2009) was used to analysis the data. descriptive statistics was used to measure the average radius of bacterial growth inhibiting for each group, ANOVA test with post-hoc Bonferroni correction and independent samples T-test were used to test the significant difference between groups.

\section{Results:}

\section{Physical properties:}

Physical properties were studied by measuring the length and consistency (after compression) of the platelet rich fibrin. Comparison has been made between the added volume of the antibiotic (0.5- $1 \mathrm{~mm}$ ), and between different forms of antibiotic (ampoule, solution, powder).

Table N.1 represents the results of the physical properties, the average length of the control sample was $(35 \pm 2.92 \mathrm{~mm})$, the average length of PRF after adding $(0.5 \mathrm{ml})$ in ampoule form was $(32.4 \pm 4.61 \mathrm{~mm})$ and with $(1 \mathrm{ml})$ was $(30.5 \pm 2.33 \mathrm{~mm})$, the average length of PRF after adding $(0.5 \mathrm{ml})$ in solution form was $(30.3 \pm 2.84 \mathrm{~mm})$ and with $(1 \mathrm{ml})$ was $(24.2 \pm 3.74 \mathrm{~mm})$, while PRF failed when adding antibiotic in powder form. No significant difference was noticed between the length and the consistency of PRF between $(0.5-1 \mathrm{ml})$ in the ampoule and the solution form.

The consistency of PRF was (100\%) for all samples (control, ampoule, solution) in both volumes (0.5 - 1 $\mathrm{ml})$, while powder failed to keep it consistency. No significant difference was noticed between $(0.5-1$ $\mathrm{ml}$ ) volume. 


\section{Antibacterial activity:}

Table N.2 shows the average bacterial growth inhibiting for both bacteria (S. aureus, E. faecalis), and between different forms and volume of the antibiotic agent.

PRF with $0.5 \mathrm{ml}$ of antibiotic in ampoule form showed the highest results in inhibiting bacterial growth, the average of ampoule form $(0.5 \mathrm{ml})$ in $\mathrm{S}$. aureus group at T1 was $(30.18 \mathrm{~mm})$ and was $(31.25 \mathrm{~mm})$ at T4. Ampoule $(1 \mathrm{ml})$ had similar results through the four-time intervals. Solution form for $(0.5 \mathrm{ml}, 1 \mathrm{ml})$ was at T1 $(24.31 \mathrm{~mm}, 25.25 \mathrm{~mm})$ retrospectively, and was $(21.38 \mathrm{~mm}, 25.5 \mathrm{~mm})$ at T4. While control group (PRF without antibiotic) had the lowest results of bacterial growth inhabiting, at T1 $(15.19 \mathrm{~mm})$, and at T4 $(7.4 \mathrm{~mm})$. Table N.2

No significant difference was noticed between ampoule and solution, while there has been significant difference between ampoule $(0.5,1 \mathrm{ml})$ and control $(P<0.05)$, and significant difference between solution form $(0.5 \mathrm{ml}, 1 \mathrm{ml})$ and control.

Bar chart N.1 represent the previous data, and shows the changes in bacterial growth inhibiting between $\mathrm{T} 1$ and $\mathrm{T} 4$. 
Table 1

- The effect of PF* on inhibiting Staph. Aureus growth.

\begin{tabular}{|c|c|c|c|c|c|c|c|}
\hline \multicolumn{2}{|c|}{$\begin{array}{l}\text { Pharmaceutical } \\
\text { form }\end{array}$} & \multirow{2}{*}{$\begin{array}{l}\text { Mean } \\
29.96\end{array}$} & \multirow{2}{*}{$\begin{array}{l}\text { ANOVA } \\
0.000\end{array}$} & \multicolumn{2}{|c|}{ Post hoc - Bonferroni test } & \multirow[b]{2}{*}{ Dep variables } & \multirow[b]{2}{*}{$P$ value } \\
\hline $\mathrm{T} 1$ & amp & & & Dep variables & $\begin{array}{l}P \\
\text { value }\end{array}$ & & \\
\hline & powder & 6.51 & & Amp - powder & 0.000 & $\begin{array}{l}\text { Powder - } \\
\text { solution }\end{array}$ & 0.000 \\
\hline & solution & 24.78 & & $\begin{array}{l}\text { Amp - } \\
\text { solution }\end{array}$ & 0.691 & Powder - control & 0.066 \\
\hline & control & 15.19 & & Amp - control & 0.000 & Solution - control & 0.033 \\
\hline \multirow[t]{4}{*}{$\mathrm{T} 2$} & amp & 32.64 & 0.000 & Dep variables & $\begin{array}{l}P \\
\text { value }\end{array}$ & Dep variables & $P$ value \\
\hline & powder & 4.14 & & Amp - powder & 0.000 & $\begin{array}{l}\text { Powder - } \\
\text { solution }\end{array}$ & 0.000 \\
\hline & solution & 27.55 & & $\begin{array}{l}\text { Amp - } \\
\text { solution }\end{array}$ & 0.176 & Powder - control & 0.003 \\
\hline & control & 12.73 & & Amp - control & 0.000 & Solution - control & 0.000 \\
\hline \multirow[t]{4}{*}{ T3 } & amp & 32.44 & 0.000 & Dep variables & $\begin{array}{l}P \\
\text { value }\end{array}$ & Dep variables & $P$ value \\
\hline & powder & 3.38 & & Amp - powder & 0.000 & $\begin{array}{l}\text { Powder - } \\
\text { solution }\end{array}$ & 0.000 \\
\hline & solution & 26.63 & & $\begin{array}{l}\text { Amp - } \\
\text { solution }\end{array}$ & 0.039 & Powder - control & 0.041 \\
\hline & control & 9.14 & & Amp - control & 0.000 & Solution - control & 0.000 \\
\hline \multirow[t]{4}{*}{$\mathrm{T} 4$} & amp & 31.65 & 0.000 & Dep variables & $\begin{array}{l}P \\
\text { value }\end{array}$ & Dep variables & $P$ value \\
\hline & powder & 3.05 & & Amp - powder & 0.000 & $\begin{array}{l}\text { Powder - } \\
\text { solution }\end{array}$ & 0.000 \\
\hline & solution & 23.44 & & $\begin{array}{l}\text { Amp - } \\
\text { solution }\end{array}$ & 0.007 & Powder - control & 0.400 \\
\hline & control & 7.40 & & Amp - control & 0.000 & Solution - control & 0.000 \\
\hline
\end{tabular}

Moreover, E. faecalis inhibiting growth is represented in Table N.2, ampoule form $(0.5 \mathrm{ml})$ was on average (24.23 $\mathrm{mm})$ at T1, and $(15.59 \mathrm{~mm})$ at T4. Ampoule form (1 ml) at T1 and T4 was $(25.6,11.5 \mathrm{~mm})$ retrospectively. Solution form $(0.5 \mathrm{ml})$ had lower results and was effective only between T1 $(21.4 \mathrm{~mm})$ and T3 $(8.5 \mathrm{~mm})$, while solution form $(1 \mathrm{~mm})$ had better results and lasted through the 4-time intervals 
( $\mathrm{T} 1=20.17 \mathrm{~mm}, \mathrm{~T} 2=14.23 \mathrm{~mm}, \mathrm{~T} 3=13.23, \mathrm{~T} 4=11.35 \mathrm{~mm}$ ). Control group had limited antibacterial activity at T1 $(12.7 \mathrm{~mm})$ and T2 $(4.72 \mathrm{~mm})$, while failed to inhibit the growth of E. faecalis at T3 and T4.

Bar chart N.2 represent the changes on bacterial growth inhibiting through the four-time intervals. Both ampoule and solution form were significantly higher compared the control group $(p<0.05)$, while no significant difference was noticed between ampoule and solution form. Best results were noticed using ampoule form with $0.5 \mathrm{ml}$ of antibiotic agent.

Table 2

- Effect of Dose, PF* on Staph. Aureus growth inhibiting

\begin{tabular}{|c|c|c|c|c|c|c|c|c|c|}
\hline \multicolumn{2}{|c|}{ Variables } & \multicolumn{2}{|l|}{ Dose } & \multicolumn{3}{|c|}{ Pharmaceutical form } & \multicolumn{3}{|c|}{ Independent sample T-test } \\
\hline & & average & $\begin{array}{l}\text { ANOVA } \\
\text { test }\end{array}$ & amp & powder & solution & $\begin{array}{l}\text { Amp } \\
0.5- \\
1 \mathrm{ml}\end{array}$ & $\begin{array}{l}\text { Pow } \\
0.5- \\
1 \mathrm{ml}\end{array}$ & $\begin{array}{l}\text { Solu } \\
0.5- \\
1 \mathrm{ml}\end{array}$ \\
\hline \multirow[t]{3}{*}{ T1 } & $0.5 \mathrm{ml}$ & 22.50 & \multirow[t]{3}{*}{0.339} & 30.18 & 13.03 & 26.31 & \multirow[t]{2}{*}{0.086} & \multirow[t]{2}{*}{0.058} & \multirow[t]{2}{*}{0.015} \\
\hline & $1 \mathrm{ml}$ & 18.33 & & 29.75 & .00 & 25.25 & & & \\
\hline & control & 15.19 & & . & . & . & & & \\
\hline \multirow[t]{3}{*}{ T2 } & $0.5 \mathrm{ml}$ & 23.12 & \multirow[t]{3}{*}{0.181} & 32.43 & 8.27 & 28.65 & \multirow[t]{2}{*}{0.713} & \multirow[t]{2}{*}{0.013} & \multirow[t]{2}{*}{0.822} \\
\hline & $1 \mathrm{ml}$ & 19.77 & & 32.85 & .00 & 26.45 & & & \\
\hline & control & 12.73 & & . & . & . & & & \\
\hline \multirow[t]{3}{*}{ T3 } & $0.5 \mathrm{ml}$ & 22.54 & \multirow[t]{3}{*}{0.060} & 32.13 & 6.75 & 28.75 & \multirow[t]{2}{*}{0.459} & \multirow[t]{2}{*}{0.008} & \multirow[t]{2}{*}{0.103} \\
\hline & $1 \mathrm{ml}$ & 19.08 & & 32.75 & .00 & 24.50 & & & \\
\hline & control & 9.14 & & . & . & . & & & \\
\hline \multirow[t]{3}{*}{$\mathrm{T} 4$} & $0.5 \mathrm{ml}$ & 19.58 & \multirow[t]{3}{*}{0.061} & 31.25 & 6.10 & 21.38 & \multirow[t]{2}{*}{0.268} & \multirow[t]{2}{*}{0.013} & \multirow[t]{2}{*}{$<0.001$} \\
\hline & $1 \mathrm{ml}$ & 19.18 & & 32.05 & .00 & 25.50 & & & \\
\hline & control & 7.40 & & . & . & & & & \\
\hline
\end{tabular}

\section{Enterococcus:}

\section{The effect of Pharmaceutical form on inhibiting Enterococcus growth in culture:}

Two forms only (ampoule, solution) of antibacterial agents (Lincomycin) were incorporated with the PRF to test the effectiveness of the new PRF on inhibiting Enterococcus growth in culture (powder was excluded because it has failed to give significant results when it was tested on Staphylococcus). 
Table N.3 represent the average radius of Enterococcus growth inhibiting, Ampoule form had the highest level of antibacterial effect during the four times of measurement (T1: 24.92, T2: $22.88, T 3=20.55, \mathrm{~T} 4=$ 4.5). Solution antibacterial effect decreased rapidly between $T 1$ and $T 4(22.78,3.33)$ retrospectively. Control samples showed very limited antibacterial effect on Enterococcus during T1, T2 $(12.70,4.72)$ and completely lost its effectiveness in T3, T4. Bar chart N.2

ANOVA test showed significant difference in $\mathrm{T} 1, \mathrm{~T} 2, \mathrm{~T} 3$, but there was no significant difference in $\mathrm{T} 4$ (0.604). Post hoc test (Bonferroni correction) was used to detect the difference within each two variables (amp, sol, con):

Table 3

- The effect of PF* on inhibiting E. faecalis growth.

\begin{tabular}{|c|c|c|c|c|c|}
\hline \multicolumn{2}{|c|}{ Pharmaceutical form } & \multirow[t]{2}{*}{ Mean } & \multirow[t]{2}{*}{ ANOVA } & \multicolumn{2}{|c|}{ Post hoc - Bonferroni test } \\
\hline & & & & Dep - variables & $P$-value \\
\hline \multirow[t]{3}{*}{$\mathrm{T} 1$} & amp & 24.92 & \multirow[t]{3}{*}{0.000} & Amp-sol & 0.069 \\
\hline & solution & 20.78 & & Amp-con & 0.000 \\
\hline & control & 12.70 & & Sol- con & 0.001 \\
\hline \multirow[t]{3}{*}{ T2 } & amp & 22.88 & \multirow[t]{3}{*}{0.000} & Amp-sol & 0.003 \\
\hline & solution & 13.35 & & Amp-con & 0.000 \\
\hline & control & 4.72 & & Sol- con & 0.006 \\
\hline \multirow[t]{3}{*}{ T3 } & amp & 20.55 & \multirow[t]{3}{*}{0.000} & Amp-sol & 0.020 \\
\hline & solution & 10.88 & & Amp-con & 0.000 \\
\hline & control & .00 & & Sol- con & 0.009 \\
\hline \multirow[t]{3}{*}{$\mathrm{T} 4$} & amp & 4.50 & \multirow[t]{3}{*}{0.604} & Amp-sol & 1.000 \\
\hline & solution & 3.33 & & Amp- con & 1.000 \\
\hline & control & 0.00 & & Sol- con & 1.000 \\
\hline * $\mathrm{P}$ & Iarmaceutical & rm. & & & \\
\hline
\end{tabular}

The effect of the added dose on inhibiting Enterococcus growth in culture

Two doses of antibiotics $(0.5 \mathrm{ml}, 1 \mathrm{ml})$ were used to test the effectiveness of the ARB on inhibiting Enterococcus growth. Very similar results were noticed between 0.5 and $1 \mathrm{ml}$ in the four times of measurements (table N.4). 
ANOVA and post hoc test results are represented in (Table N.4). No significant differences were noticed between $0.5-1 \mathrm{ml}$ dose of the ampoule form.

Table 4

- effect of Dose, PF* on Enterococcus growth inhibiting

\begin{tabular}{|c|c|c|c|c|c|c|c|c|c|}
\hline \multicolumn{2}{|c|}{ Variables } & \multicolumn{4}{|l|}{ Dose } & \multicolumn{2}{|c|}{$\begin{array}{l}\text { Pharmaceutical } \\
\text { form }\end{array}$} & \multicolumn{2}{|c|}{$\begin{array}{l}\text { Independent } \\
\text { sample T-test }\end{array}$} \\
\hline & & \multirow{2}{*}{$\begin{array}{l}\text { Average } \\
22.82\end{array}$} & \multirow{2}{*}{$\begin{array}{l}\begin{array}{l}\text { ANOVA } \\
\text { test }\end{array} \\
0.000\end{array}$} & \multicolumn{2}{|c|}{ Post hoc test } & \multirow{2}{*}{$\begin{array}{l}\text { Ampoule } \\
24.23\end{array}$} & \multirow{2}{*}{$\begin{array}{l}\text { Solution } \\
21.40\end{array}$} & \multirow{2}{*}{$\begin{array}{l}\text { Amp } \\
0.5- \\
1 \mathrm{ml} \\
0.086\end{array}$} & \multirow{2}{*}{$\begin{array}{l}\text { Sol } \\
0.5- \\
1 \mathrm{ml} \\
0.523\end{array}$} \\
\hline $\mathrm{T} 1$ & $0.5 \mathrm{ml}$ & & & $\begin{array}{l}0.5- \\
1 \mathrm{~mL}\end{array}$ & 1.000 & & & & \\
\hline & $1 \mathrm{ml}$ & 22.88 & & $\begin{array}{l}0.5 \mathrm{ml}- \\
\text { con }\end{array}$ & 0.000 & 25.60 & 20.17 & & \\
\hline & control & 12.70 & & $\begin{array}{l}1 \mathrm{ml}- \\
\text { con }\end{array}$ & 0.000 & . & . & & \\
\hline \multirow[t]{3}{*}{ T2 } & $0.5 \mathrm{ml}$ & 18.27 & 0.001 & $\begin{array}{l}0.5- \\
1 \mathrm{~mL}\end{array}$ & 1.000 & 24.07 & 12.47 & 0.408 & .992 \\
\hline & $1 \mathrm{ml}$ & 17.97 & & $\begin{array}{l}0.5 \mathrm{ml}- \\
\text { con }\end{array}$ & 0.003 & 21.70 & 14.23 & & \\
\hline & control & 4.72 & & $\begin{array}{l}1 \mathrm{ml}- \\
\text { con }\end{array}$ & 0.004 & . & . & & \\
\hline \multirow[t]{3}{*}{ T3 } & $0.5 \mathrm{ml}$ & 16.25 & 0.001 & $\begin{array}{l}0.5- \\
1 \mathrm{~mL}\end{array}$ & 1.000 & 23.97 & 8.53 & 0.786 & 0.699 \\
\hline & $1 \mathrm{ml}$ & 15.18 & & $\begin{array}{l}0.5 \mathrm{ml}- \\
\text { con }\end{array}$ & 0.003 & 17.13 & 13.23 & & \\
\hline & control & .00 & & $\begin{array}{l}1 \mathrm{ml}- \\
\mathrm{con}\end{array}$ & 0.005 & . & . & & \\
\hline \multirow[t]{3}{*}{$\mathrm{T} 4$} & $0.5 \mathrm{ml}$ & 4.50 & 0.604 & $\begin{array}{l}0.5- \\
1 \mathrm{~mL}\end{array}$ & 1.000 & 9.00 & .00 & 0.016 & 0.016 \\
\hline & $1 \mathrm{ml}$ & 3.33 & & $\begin{array}{l}0.5 \mathrm{ml}- \\
\text { con }\end{array}$ & 1.000 & .00 & 6.67 & & \\
\hline & control & .00 & & $\begin{array}{l}1 \mathrm{ml}- \\
\mathrm{con}\end{array}$ & 1.000 & & . & & \\
\hline
\end{tabular}

\section{Discussion:}

Clinicians have been using PRF and other platelet concentration products with the regenerative procedure in order to enhance the healing and to reduce the postoperative complications (24), however, studies have shown that PRF have only mild antibacterial activity against some bacterial agents like $S$. aureus, and it 
is not affective against resistance bacteria like $F$. Nucleatum $(25,26)$. Moreover, the most frequent postoperative complication in minor surgery is infection due to the exposure of the flap (or membrane) and the bacterial colonization of the wound $(21,27)$.

Therefore, this research aimed to improve the antibacterial activity of PRF by adding different forms of antibiotics and developing a reproducibly protocol which produce PRF with best antibacterial activity and best physical properties.

PRF that has a high antibacterial activity would be very effective where infection is predictable, and can reduce the need of antibiotic especially in the field of dental surgeries (28), and can help to reduce the use and side effect of systematic antibiotic (cell toxicity, and antibiotic resistance) (29).

Several studies tried to improve the antibacterial activity of PRF, one study added silver nanoparticles (SNP) which created SNP modified PRF, and this study concluded that SNP modified PRF had an improved mechanical properties and higher antimicrobial activity (20), other study evaluated release kinetics of different antibiotic from PRF, the results showed that PRF could release antibiotics for a week (30).

Three forms of antibiotic were tested, ampoule $(0.5,1 \mathrm{ml})$ solution $(0,5,1 \mathrm{ml})$ had the best results and did not change the physical properties of the PRF, while PRF failed to form when adding powder form of antibiotic. The reason to test different forms of antibiotic agent is to give the clinician variety of options during the practical practice.

Results showed that adding ampoule or solution form can significantly increase the antibiotic activity of PRF, compared with normal PRF (control), and could release antibiotic for 10 days. No significant difference between ampoule and solution form was noticed, however, ampoule had higher results, this can be explained because ampoule is already prepared for IV, IM injection while the solution concentration may have been diluted in the serum. No previous study had studied the effect of pharmaceutical form on the antibiotic release of PRF. Also, $0.5 \mathrm{ml}$ and $1 \mathrm{ml}$ volume had similar results, however, $0.5 \mathrm{ml}$ had a slightly higher antibacterial activity, which agrees with the results of previous study (19).

The protocol used in this study succeed to improve the antibacterial activity of PRF preserved the physical properties of the PRF. The antibiotic release in our study lasted for 10 days, other study recorded that the bacterial growth inhabitation lasted between $4-7$ days $(19,30)$.

This results can be helpful in oral surgery were infection is the main complication and the main source of failure (21), oral surgeries and treating of periodontal diseases can improve by the gradual local release of antibiotic (37).

Further research and improvement should be done to the protocol proposed in this study using different antibiotic agents and bacteria in order to prepare this concept for the clinical application. 
Finally, and Within the limits of this study, it can conclude that the proposed protocol in this study has succeeded to improve the antibacterial properties of PRF, creating a local antibiotic delivery biomaterial that can be used widely after minor surgery, and can significantly reduce the use of systematic antibiotics.

\section{Conclusion:}

The protocol proposed in this study succeeded to improve the antibacterial activity of the PRF with preserving the physical properties. No significant difference in physical properties were noticed between control group and PRF with antibiotic. Best results of bacterial inhibiting were noticed when adding $0.5 \mathrm{ml}$ of ampoule form to the PRF using the protocol of this study, however, no significant results were noticed between the different forms and volume of the antibiotic.

\section{Declarations}

Ethics approval and consent to participate:

The research ethical approval reference number is 135\S - data: 15-12-2019, and it was obtained from the scientific committee at the faculty of dental medicine, and the ethical committee at Damascus university

\section{Consent for publication}

Not applicable.

\section{Availability of data and material}

All necessary data are presented within the manuscript. All other materials and data are available upon request for reasonable reason. For any more details regarding the data of this research please contact the corresponded author.

\section{Competing interests}

The authors declared no potential conflicts of interest with respect to the research, authorship and/or publication of this article.

\section{Funding}

No funding.

\section{Authors' contributions}

A.B: developed the idea, designed the research, wrote the manuscript, analyzed the data, finalized the manuscript. 
S.L: Bacterial isolation and culture, data collection, helped writing the manuscript.

S.C: helped with laboratory procedure, reviewed the article.

S.A.A: reviewed the article, helped finalizing the manuscript.

\section{References}

1. Prakash S, Thakur A. Platelet concentrates: past, present and future. J Maxillofac Oral Surg. 2011;10(1):45-9.

2. Dohan Ehrenfest DM, Andia I, Zumstein MA, Zhang CQ, Pinto NR, Bielecki T. Classification of platelet concentrates (Platelet-Rich Plasma-PRP, Platelet-Rich Fibrin-PRF) for topical and infiltrative use in orthopedic and sports medicine: current consensus, clinical implications and perspectives. Muscles Ligaments Tendons J. 2014;4(1):3-9.

3. Polimeni G, Xiropaidis AV, Wikesjo UM. Biology and principles of periodontal wound healing/regeneration. Periodontol 2000. 2006;41:30-47.

4. Shah R, M GT, Thomas R, Mehta DS. An Update on the Protocols and Biologic Actions of Platelet Rich Fibrin in Dentistry. Eur J Prosthodont Restor Dent. 2017;25(2):64-72.

5. Borzini P, Mazzucco L. Platelet gels and releasates. Curr Opin Hematol. 2005;12(6):473-9.

6. Valenti Azcarate A, Lamo-Espinosa J, Aquerreta Beola JD, Hernandez Gonzalez M, Mora Gasque G, Valenti Nin JR. Comparison between two different platelet-rich plasma preparations and control applied during anterior cruciate ligament reconstruction. Is there any evidence to support their use? Injury. 2014;45 Suppl 4:S36-41.

7. Marx RE. Platelet-rich plasma: evidence to support its use. J Oral Maxillofac Surg. 2004;62(4):48996.

8. Badran Z, Abdallah MN, Torres J, Tamimi F. Platelet concentrates for bone regeneration: Current evidence and future challenges. Platelets. 2018;29(2):105-12.

9. Dohan DM, Choukroun J, Diss A, Dohan SL, Dohan AJ, Mouhyi J, et al. Platelet-rich fibrin (PRF): a second-generation platelet concentrate. Part I: technological concepts and evolution. Oral Surg Oral Med Oral Pathol Oral Radiol Endod. 2006;101(3):e37-44.

10. Sunitha Raja V, Munirathnam Naidu E. Platelet-rich fibrin: evolution of a second-generation platelet concentrate. Indian journal of dental research : official publication of Indian Society for Dental Research. 2008;19(1):42-6.

11. Mosesson MW, Siebenlist KR, Meh DA. The structure and biological features of fibrinogen and fibrin. Ann N Y Acad Sci. 2001;936:11-30.

12. Dohan DM, Choukroun J, Diss A, Dohan SL, Dohan AJ, Mouhyi J, et al. Platelet-rich fibrin (PRF): a second-generation platelet concentrate. Part II: platelet-related biologic features. Oral Surg Oral Med Oral Pathol Oral Radiol Endod. 2006;101(3):e45-50. 
13. Kour P, Pudakalkatti PS, Vas AM, Das S, Padmanabhan S. Comparative Evaluation of Antimicrobial Efficacy of Platelet-rich Plasma, Platelet-rich Fibrin, and Injectable Platelet-rich Fibrin on the Standard Strains of Porphyromonas gingivalis and Aggregatibacter actinomycetemcomitans. Contemp Clin Dent. 2018;9(Suppl 2):S325-s30.

14. Zrnc TA, Metzler P, Zemann W, Ghanaati S. PRF in dentistry - a short synopsis about implementation and workflow. Swiss Dent J. 2018;128(9):712-3.

15. Lektemur Alpan A, Torumtay Cin G. PRF improves wound healing and postoperative discomfort after harvesting subepithelial connective tissue graft from palate: a randomized controlled trial. Clin Oral Investig. 2020;24(1):425-36.

16. Xie H, Xie YF, Liu Q, Shang LY, Chen MZ. [Bone regeneration effect of injectable-platelet rich fibrin (IPRF) in lateral sinus lift: a pilot study]. Shanghai Kou Qiang Yi Xue. 2019;28(1):71-5.

17. Pitzurra L, Jansen IDC, de Vries TJ, Hoogenkamp MA, Loos BG. Effects of L-PRF and A-PRF+ on periodontal fibroblasts in in vitro wound healing experiments. J Periodontal Res. 2019.

18. Fujioka-Kobayashi M, Miron RJ, Hernandez M, Kandalam U, Zhang Y, Choukroun J. Optimized Platelet-Rich Fibrin With the Low-Speed Concept: Growth Factor Release, Biocompatibility, and Cellular Response. J Periodontol. 2017;88(1):112-21.

19. Polak D, Clemer-Shamai N, Shapira L. Incorporating antibiotics into platelet-rich fibrin: A novel antibiotics slow-release biological device. Journal of clinical periodontology. 2019;46(2):241-7.

20. Khorshidi H, Haddadi P, Raoofi S, Badiee P, Dehghani Nazhvani A. Does Adding Silver Nanoparticles to Leukocyte- and Platelet-Rich Fibrin Improve Its Properties? Biomed Res Int. 2018;2018:8515829.

21. Heal C, Buettner P, Browning S. Risk factors for wound infection after minor surgery in general practice. Med J Aust. 2006;185(5):255-8.

22. Zeiler T, Kretschmer VV. Platelet Concentrates from Automated Apheresis - Past, Present and Future Developments. Infusionsther Transfusionsmed. 2000;27(3):119-26.

23. GUPTA V, BAINS, V. K., SINGH, G., MATHUR, A. \& BAINS, R. . Regenerative potential of platelet rich fibrin in dentistry: literature review. Asian Journal of Oral Health \& Allied Sciences. 2011;1:23-8.

24. Castro AB, Meschi N, Temmerman A, Pinto N, Lambrechts P, Teughels W, et al. Regenerative potential of leucocyte- and platelet-rich fibrin. Part A: intra-bony defects, furcation defects and periodontal plastic surgery. A systematic review and meta-analysis. Journal of clinical periodontology. 2017;44(1):67-82.

25. Bielecki TM, Gazdzik TS, Arendt J, Szczepanski T, Krol W, Wielkoszynski T. Antibacterial effect of autologous platelet gel enriched with growth factors and other active substances: an in vitro study. J Bone Joint Surg Br. 2007;89(3):417-20.

26. Moojen DJ, Everts PA, Schure RM, Overdevest EP, van Zundert A, Knape JT, et al. Antimicrobial activity of platelet-leukocyte gel against Staphylococcus aureus. J Orthop Res. 2008;26(3):404-10.

27. Zhang J, Xu Q, Huang C, Mo A, Li J, Zuo Y. Biological properties of an anti-bacterial membrane for guided bone regeneration: an experimental study in rats. Clin Oral Implants Res. 2010;21(3):321-7. 
28. McLaren AC. Alternative materials to acrylic bone cement for delivery of depot antibiotics in orthopaedic infections. Clin Orthop Relat Res. 2004(427):101-6.

29. Verdel BM, van Puijenbroek EP, Souverein PC, Leufkens HG, Egberts AC. Drug-related nephrotoxic and ototoxic reactions : a link through a predictive mechanistic commonality. Drug Saf. 2008;31(10):87784.

30. Knafl D, Thalhammer F, Vossen MG. In-vitro release pharmacokinetics of amikacin, teicoplanin and polyhexanide in a platelet rich fibrin-layer (PRF)-a laboratory evaluation of a modern, autologous wound treatment. PLoS One. 2017;12(7):e0181090.

31. Smith AJ, Jackson MS, Bagg J. The ecology of Staphylococcus species in the oral cavity. J Med Microbiol. 2001;50(11):940-6.

32. Molander A, Reit C, Dahlen G, Kvist T. Microbiological status of root-filled teeth with apical periodontitis. Int Endod J. 1998;31(1):1-7.

33. Rajkumari N, Mathur P, Misra MC. Soft Tissue and Wound Infections Due to Enterococcus spp. Among Hospitalized Trauma Patients in a Developing Country. J Glob Infect Dis. 2014;6(4):189-93.

34. Schimmel J, Belcher M, Vieira C, Lawrence N, Decker A. Incidence of Surgical Site Infections in Second Intention Healing After Dermatologic Surgery. Dermatol Surg. 2020.

35. Soon SL. Commentary on Incidence of Surgical Site Infections in Second Intention Healing After Dermatologic Surgery. Dermatol Surg. 2020.

36. Prada C, Tanner SL, Marcano-Fernandez FA, Bzovsky S, Schemitsch EH, Jeray K, et al. How Successful Is Antibiotic Treatment for Superficial Surgical Site Infections After Open Fracture? A Fluid Lavage of Open Wounds (FLOW) Cohort Secondary Analysis. Clin Orthop Relat Res. 2020.

37. Chen AF, Brown GA. Management of Surgical Site Infections. J Am Acad Orthop Surg. 2020;28(6):e238-e41.

\section{Figures}




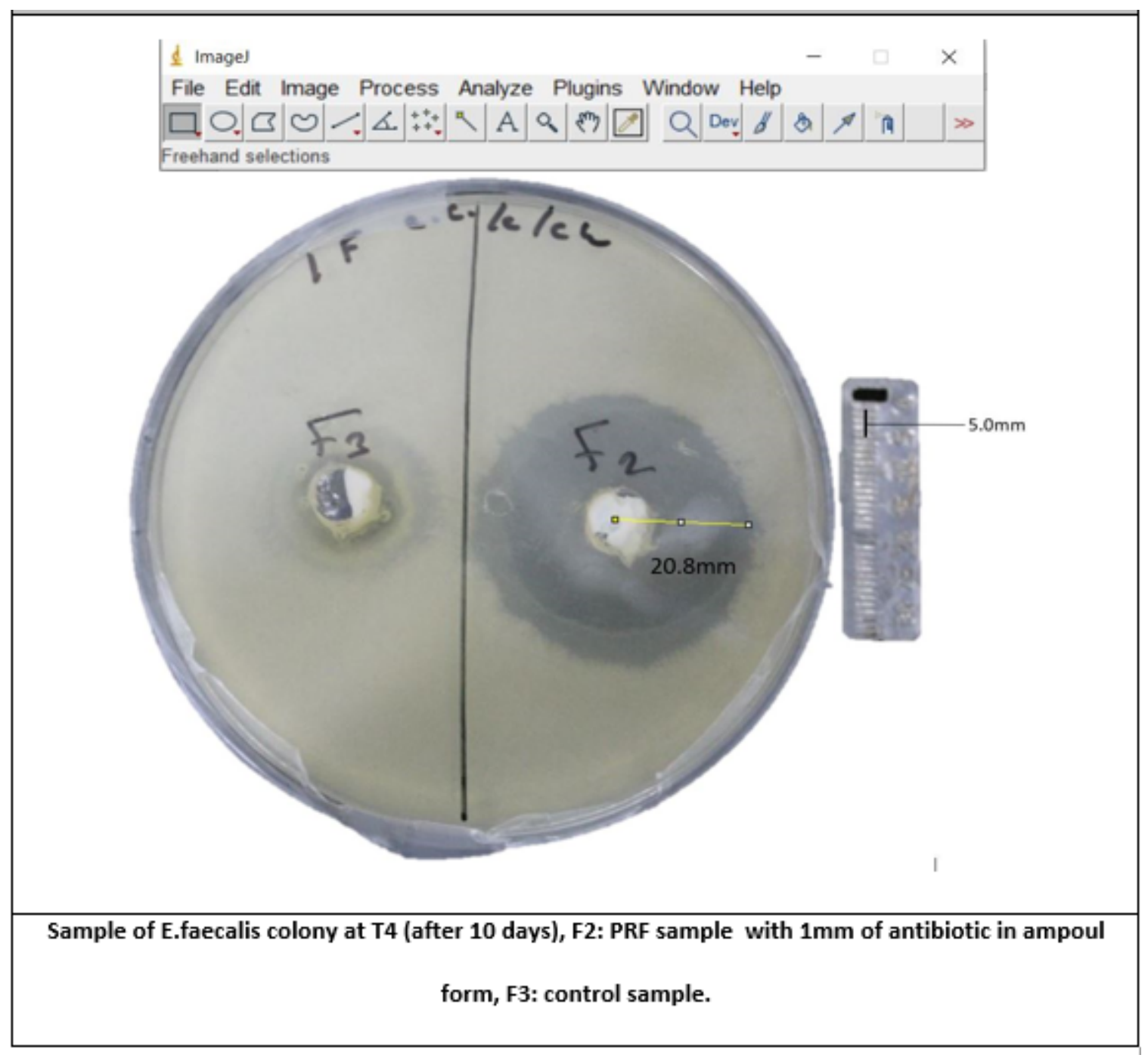

\section{Figure 1}

measuring the radius of bacterial growth inhibiting using Image-J 